Ann. Biol. anim. Bioch. Biophys., 1978, 18 (4), 851-856.

\title{
Scanning cytophotometry : A method for studying the amount of neurosecretory material in the preoptic nucleus of the trout (Salmo gairdneri)
}

\author{
par M. TERLOU, J. P. DE JONG, P. G. W. J. VAN OORDT \\ Zoological Laboratory, Section Comparative Endocrinology, \\ Padualaan 8, Utrecht, The Netherlands.
}

Summary. In order to study the activity of the preoptic nucleus (NPO) during the annual cycle, the amount of neurosecretory material was measured by means of scanning cytophotometry. This objective method implies standardization of the histological method and computerized procedures for the analysis of the data. Preliminary results of such studies on the NPO of sexually mature male rainbow trout, together with cytological information, point to cyclical changes in the activity of the nucleus. An active period was indicated from the beginning of June to January and an inactive period from February to June.

\section{Introduction.}

The hypothalamic regulation of the pituitary gland in salmonids is controlled by at least 3 types of neurosecretory systems, i. e. the peptidergic AF-positive nucleus preopticus (NPO), the peptidergic AF-negative nucleus lateralis tuberis (NLT) and the monoaminergic nucleus recessus lateralis and nucleus recessus posterioris. Fibers are projected from these centers onto the hypophysis. The NPO fibers mostly terminate in the caudal neurohypophysis, whereas only a few of them seem to end in the rostral neurohypophysis close to the pars distalis. Although the NLT fibres are difficult to trace, they are assumed to end primarily at the rostral neuro-adenohypophysial interface. In the Atlantic salmon and the rainbow trout, monoaminergic fibres have also been demonstrated at the neuro-adenohypophysial interface. The NLT is assumed to control the activity of the gonadotropic cells in the hypophysis. This is based on correlative changes in the activity of the NLT during the reproductive cycle, and on the effect of castration and lesion experiments (Peter, 1970 ; Zambrano, 1971 ; Holmes and Ball, 1974). However, changes in the amount of neurosecretory material (NSM) in the NPO, which can be correlated to phases in the reproductive cycle are indications that the NPO is involved as well (Ball and Baker, 1969 ; Holmes and Ball, 1974). An indirect role of the NPO via the NLT was strongly advocated by Weiss (1976) and Ekengren and Terlou (1978), because NPO fibres running towards the pituitary are in direct contact with cell bodies of the lateral part of the NLT. For these 
reasons, it seemed worthwhile to include the NPO in studies on hypothalamic control of pituitary function in relation to reproductive processes. In the present study the amount of NSM is used as a criterium to quantify the activity of the NPO during the annual cycle.

As visual estimates are rather irregular and subjective, the measurements have been carried out by scanning cytophotometry. The regions of the NPO were measured separately for differential analytical purposes.

\section{Materials and methods.}

Three-year old sexually mature male trout (Salmo gairdneri) were obtained from a hatchery in Vaassen (The Netherlands). Before decapitation the animals were anesthetized with MS 222 (0.035 p. 100) or carbon dioxide gas. The brain was dissected out, fixed in Bouin-Hollande for 2-3 days, dehydrated, and embedded in paraffin wax. Bieniarz (1974) described a circadian rhythm in the amount of NSM in the NPO, and for that reason the animals were fixed between 13.30 and $15.00 \mathrm{hrs}$. A total of 10 specimens was used throughout the annual cycle (see table 1). Transverse sections of 6 microns were cut and every 11 th section was mounted on an object glass. To demonstrate the presence of NSM, the sections were stained with p-rosanilincrotonaldehyde according to Bock and Ockenfels (1970; p-rosanilin instead of Diaminobenzophenon). For quantification studies this method has the advantage of not requiring a differentiation step. In order to obtain mutually comparable material and to minimize changes due to histological procedures, the following precautions were taken : (1) sectioning was carried out with one and the same microtome, (2) after mounting the sections from all animals, oxydation was carried out before staining (oxydation time : $2 \mathrm{~min}$.) ; the oxydation step was standardized by refreshing one-third of the Gomori mixture for every subsequent rack of 10 slides, (3) staining was carried out with one batch of dye (staining time : $1 \mathrm{~min}$.).

NSM meosurement. - The light transmission in tissue containing the NPO was determined by means of a Zeiss scanning cytophotometer and with monochromatic light of $620 \mathrm{~nm}$. This wavelength produces the highest absorption of p-rosanilin-stained tissue components and prevents interference of the phloxin counterstain. Scanning was carried out in meander mode, measuring adjacent (not overlapping) square areas of $36 \mu \mathrm{m}^{2}$. The background transmission value was set at 100 p. 100 for a representative and homogeneously structured area lateral to the NPO. In order to analyse the amount of NSM in different parts of the NPO, areas with different morphological cell types were measured separately. The papertape with cytophotometer data was fed into a computer. The first computer program included the selection of values (all values higher than 96 p. 100 transmission were rejected), frequency distribution over 20 transmission classes (ranging from 0-100 p. 100), and the conversion of transmission into extinction values. The extinction is linearly proportional to the concentration of NSM. All procedures are carried out per area. The results were printed and punched on cards, which in the next program were combined per left/right half of the section, because most of the transverse sections were not perfectly symmetrical. The results per left/right section were printed and plotted in 3 graphs : 1) total extinc- 
tion per left/right section versus longitudinal axis of the brain (=NPO), giving the distribution of the amount of NSM over the whole NPO ; 2) mean extinction versus longifudinal axis of the brain ; 3) cumulative percentages of the size of the 20 transmission classes versus the longitudinal axis of the brain (fig.). Graphs 2 and 3 show the density distribution of NSM in the whole NPO.

Trout 67

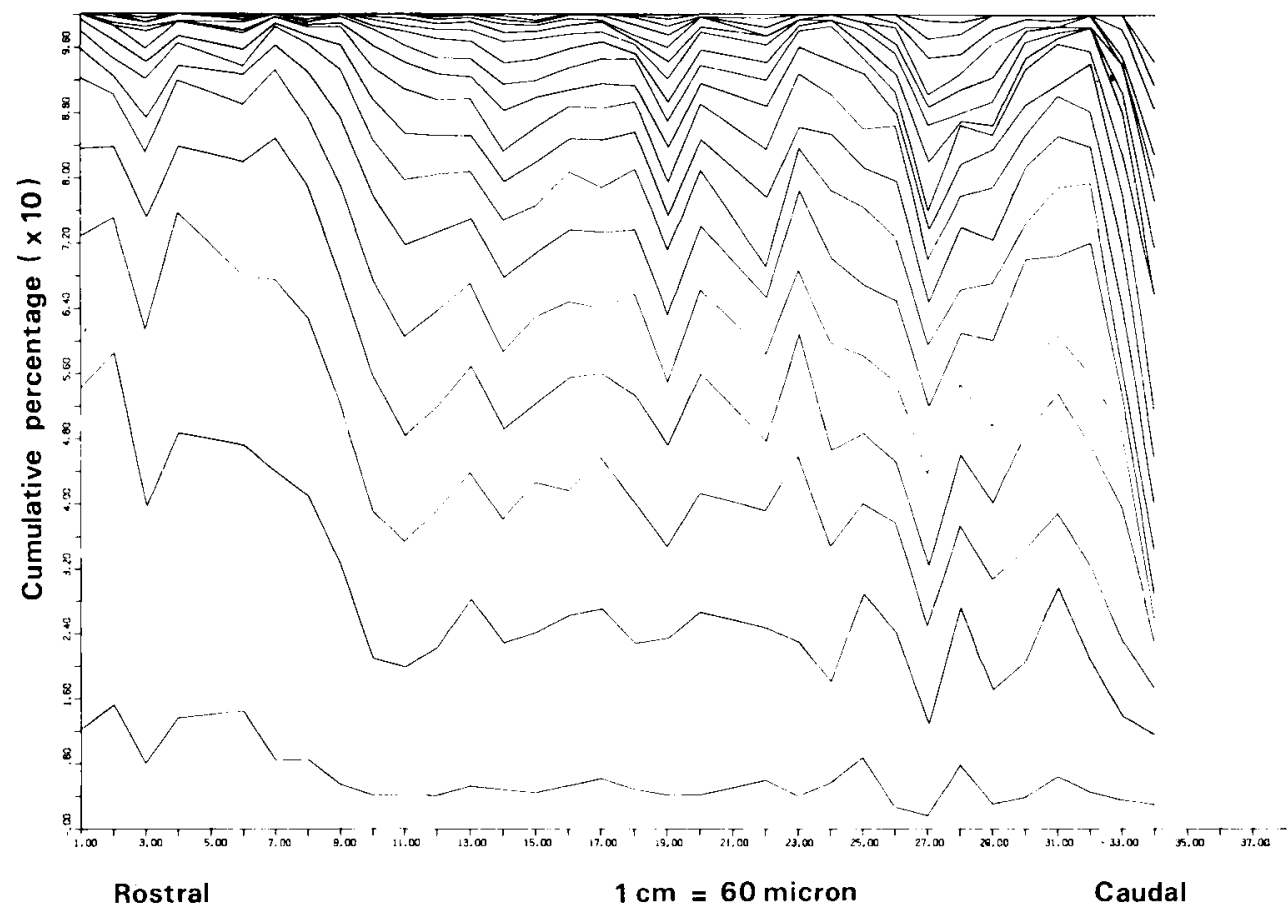

LENGTH AXIS OF THE BRAIN

FIG.

\section{Results.}

The amount of NSM of the whole NPO, as represented by the total extinction, varies during the annual cycle just as the mean extinction (table 1). The NSM was high at the beginning of June, decreased during autumn (except in trout 21) and increased during January and February (spawning period). After February, the NSM decreased again, and increased in June. The mean extinction reveals a similar pattern.

Visual examination of the sections showed that the preoptico-hypophysial tract originating from the NPO was filled with NSM from June to November. In this period the NPO cells contained active, swollen nuclei, with evenly distributed chromatin ; the nuclei contained a few (2-8) small nucleoli. In November NSM in the tract had diminished, and this was accompanied by a reduced activity of the nuclei in the NPO 
cells. In January, the activity of the cells increased and more NSM was observed in the tract. From February to June, the NPO-cells were distinctly less active. The nuclei contained one or two large nucleoli, and the chromatin was irregularly distributed.

TABLE 1

Changes in the amount of neurosecretory material measured by scanning cytophotometry af various periods of the reproductive cycle of male rainbow trout

\begin{tabular}{rccc}
\hline Trout & Date & Total extinction & Mean ext. \\
\hline 5 & $3-6-75$ & 34270 & 0.128 \\
15 & $7-8-75$ & 16339 & 0.083 \\
16 & $7-8-75$ & 18164 & 0.077 \\
21 & $24-9-76$ & 51856 & 0.145 \\
31 & $19-11-75$ & 14945 & 0.069 \\
40 & $7-1-76$ & 40329 & 0.093 \\
46 & $25-2-76$ & 42928 & 0.115 \\
53 & $25-2-76$ & 26104 & 0.075 \\
61 & $5-5-76$ & 13081 & 0.055 \\
67 & $9-6-76$ & 44043 & 0.153 \\
\hline
\end{tabular}

The tracts did not contain any noticeable NSM. In June, the tracts were filled again and the cells reactivated. The analysis of the different parts of the NPO has not been finished yet. Differences in the quality of the NSM, however, have already been determined. As an example, the figure shows the cumulative percentages of consecutive classes of the frequency distribution versus the longitudinal axis of the brain of trout 67. The class with the lowest density is situated near the $X$-axis and the class with the highest density at the top of the graph. Evaluation proved the NPO to be composed of 3 regions : 1) section nr. 1-10: NSM is present in low densities ; in section nr. 7 and the following sections NSM is found in progressively higher density classes, 2) section nr. 11-18: NSM in higher densities, rather evenly distributed in the density scale, 3) section nr. 18-34 : NSM is characterized by a changing composition ; most of the highest densities are found in this part of the NPO. This distribution corresponds to the regional distribution of cell types: rostrally the pars parvocellularis (with mediumsized magnocellular cells in the middle part) and dorso-caudally the pars magnocellularis with the largest cells of the NPO.

\section{Discussion.}

Scanning cytophotometry has proved to be an accurate and objective method for determining the amount of NSM in the NPO. The present study, based on experiments with a limited number of test animals, points to cyclic changes in the activity of the NPO during the year. As a result of synthesis and release, the amount of NSM together with cytological information (nucleus size, chromatin distribution and nucleolus morphology) indicates an active period from the beginning of June to January, with a possible decrease in November, and an inactive period from February to June. Addi- 
tional work is in progress to complete and confirm these results, which do not wholly agree with those of Sterba and Weiss (1968). A visual estimate of the amount of pseudoisocyanin-positive NSM in the NPO of the brook trout indicates an annual cycle with a maximum in November, December and January (spawning period), and a gradual leveling off until August, followed by a rise until November. Sterba and Weiss did not observe a marked increase in June. The presently observed maximum during the spawning period seems to be a common feature which was noticed also in other salmonid species by Arvy et al. (1959) and Barannikova $(1961,1963)$. In addition, those authors reported a correlation between changes in the amount of NSM and changes in salinity of the water and in thyroid activity, which together suggest a multifunctional role of the NPO. Results of the present study do not contradict this hypothesis. Based on a qualitative analysis of NSM, three different areas can be distinguished in the NPO, each containing a morphologically different cell type. It is known that arginin, vasotocin and isotocin are formed in the NPO (see Perks, 1969). Immunofluorescence indicates these hormones to be produced in different cell types, each with a preferential localization in the NPO (Dierickx and Goossens, pers. commun.). Whether other hormones are synthesized in the NPO, e. g. somatostatin (see, Doerr-Schott and Dubois, 1977), must be investigated. The morphological relation of the NPO directly in the pituitary, or indirectly via other hypothalamic nuclei (e. g. NLT), finally determines the potential of the nucleus to regulate different hypophysial functions. The relations between NPO activity and various endocrine processes should be experimentally investigated.

Symposium sur la Reproduction des Poissons Paimpont, France, 19-21 septembre 1977.

Résumé. Afin d'étudier l'activité du nucleus préoptique (NPO) de truites Arc-en-ciel mâles pendant le cycle annuel, la quantité de matériel neurosécrétoire a été mesurée au moyen de cytophotométrie à balayage. Cette méthode objective a demandé la standardisation du procédé histologique et l'intervention d'un ordinateur pour l'analyse des valeurs obtenues. Des résultats préliminaires de telles études du NPO, liés avec des données cytologiques, indiquent des changements cycliques dans l'activité du NPO. Une période active a été trouvée dès le début du mois de juin jusqu'à janvier et une période inactive de février à juin.

\section{References}

ARVY L., FONTAINE M., GABE M., 1959. La voie neurosécrétrice hypothalamo-hypophysaire des téléostéens. J. Physiol., 51, 1031-1085.

BALL J. N., BAKER B. I., 1969. The pituitary gland : anatomy and histophysiology, 1-110. In HOAR W. S., RANDALL D. J., Fish physiology, vol. II, Acad. Press, N. Y., London.

BARANNIKOVA I. A., 1961. The functional morphology of the hypothalamo-hypophysial neurosecretory system in salmon at different stages of the life cycle. Dokl. Akad. Nauk SSSR, 136, 730734.

BARANNIKOVA I. A., 1963. Das hypothalamo-hypophysäre System und die Wanderungen der Salmoniden und Acipenseriden. Biol. Rundschou, 1, 164-173.

BIENIARZ K., 1974. Circadian rhythm in the content of neurosecretory material « Gomori-positive » in the cells of nucleus preopticus of the Rainbow trout (Salmo irideus Gibbons). J. in terdiscipl. Cycle Res., 5, 115-117. 
BOCK R., OCKENFELS H., 1970. Fluoreszenzmikroskopische Darstellung Aldehydfuchsin-positive Substanzen mit Crotonaldehyd-Diaminobenzophenon. Histochemie, 21, 181-188.

DOERR-SCHOTT J., DUBOIS M. P., 1977. Immunohistochemical demonstration of an SRIF-like system in the brain of the reptile Lacerta muralis Laur. Experientia, 33, 947-949.

EKENGREN B., TERLOU M., 1978. Hypothalamic centers and innervation of the hypophysis in the Atlantic salmon (Salmo salar) and the rainbow trout (Salmo gairdneri). Ann. Biol. anim. Bioch. Biophys., 18, 837-842.

HOLMES R. L., BALL J. N., 1974. The pituitary gland, a comparative account. Cambridge Univ. Press.

PERKS A. M., 1969. The neurohypophysis, 111-205. In HOAR W. S., RANDALL D. J., Fish physiology, vol. II, Acad. Press, N. Y., London.

PETER R. E., 1970. Hypothalamic control of thyroid gland and gonadal activity in the goldfish Carassius auratus. Gen. comp. Endocr., 14, 334-356.

STERBA G., WEISS J., 1968. Beiträge zur Hydrencephalokrinie : Il. Saisonale und altersbedingte Veränderungen der hypothalamischen Hydrencephalokrinie bei der Bachforelle (Salmo trutta fario). J. Hirnforsch., 10, 49-54.

WEISS J., 1976. Untersuchungen zur Innervation des Nucleus lateralis tuberis der Bachforelle (Salmo trutto forio). Biol. Zbl., 96, 43-56.

ZAMBRANO D., 1971. The nucleus lateralis fuberis system of the gobiid fish Gillichthys mirabilis. III. Functional modifications of the neurons and gonadotropic cells. Gen. comp. Endocr., 17, 164-182. 